\title{
The Behavioral attributesAbout Nuptialsin Islam
}

\author{
Dr. Abdul Hai Al-Madni \\ Associate Professor, Humanities department, NED University,Karachi, Pakistan
}

\begin{abstract}
:
Allah has indeed created man and woman to be the natural counterparts of the other, they are natural companions so He has destined that they will find comfort and repose with one another. The foundation of a Muslim marriage is that the physical, emotional and mental bonding and companionship must be firmly based upon love and compassion, only then can husband and wife truly find comfort in one another.

For this purpose Islamic guidelines also lead and viewed the marriage relationship as private part in life and a source of human reproduction. It is clear concept the husband and wife must seek to sexually satisfaction through lawful way only. Sex is a human desire that should be fulfilled in any way and Islam does not take the negligence about this vital need so he gave his decent consideration about sex experience.

The marriage concept in Islam does not mean the sexual satisfaction only but the both of should be receptive to another needs, and the husband should remember Allah to purify his mind before intercourse and they are commanded not to treat their wives harshly for the purpose of getting back anything.

The Non-Muslims who have raised some objection about Islamic concept about sex with so many unfair and groundless accusations.

We have trying to introduce Islamic ideas about sex in human life. If the Islamic point of view becomes clear in the minds of non-Muslim, so hoped that they would understand the Islam.

My first attempts to present the Islamic point of view about sex specific man-woman relationship. And hope that article would offer a general view for those who are interested to know the stand point about this important social issue.
\end{abstract}

\section{Keywords:}

Concept ,purification, matrimony, procedure , Mutual rights, sexual relationship,Sexual freedom and confusion.

\section{Council for Innovative Research}

Peer Review Research Publishing System Journal of Social Science Researh

Vol3, No.3

editor@jssronline.com

www.cirworld.com, www.jssronline.com 


\section{Consociation between the Spouses:}

The Islamic society is governed by complete rules especially for family. Islam gave woman the honor and requires that she be treated with respect. And her sexuality is not exploited in any way. Also to the side of man he have the exclusive right of sexual access to his wife but also the right that her beauty and feminine attractions should not be shared with other men, and the same is true of the wife in relation to her husband.

This relationship based on the general rules and regulation, so Islam established some principles related this relationship.

And these principles based on are not permitted to free, casual social mixing between men and women. For this rule in society just like schools, colleges, hospitals, transportation facilities, etc., have separate sections between men and women.

the construction of homes in different portions that men visitors can came to specific portion so male visitors are received by the men of the house and entertained in a guest room, while the women welcome women on their own activities in their informal home attire in other parts of the house without being seen by the male visitors in any way.

Also the Muslim woman is required to conceal her all attractions from men by a strictly modest, straightforward type of attire. Within the close family circle, she is free to dress informally and to beautify herself for her husband only. So her beauty is reserved for him. And outside of her home in the presence of non-related men she is required to wear a covering-type of dress.

It is most important and experienced Due to this modest dress and the propriety of her manner and behavior, men can regard and treat her as a person not a sex object.

But lest it be thought that the responsibility for maintaining pure relations with the opposite sex rests with women alone, we have only to cite the following well-known Qur'anic verse:

"Tell the believing men to lower their gaze 1 and guard their sexuality; that is purer for them. Indeed, God is aware of what they do. And tell the believing women to lower their gaze and guard their sexuality..." (1)

\section{Sex conception In Islam:}

Islam considers the sex is basic essentialhuman needs must be properly fulfilled. It is a necessity of the humanbeing. It requires favorable consideration. Islam does not treat it as a distasteful, filthy, or heinous act ofman. Allah states in Quran:Beautified for men is the love of things they covet; women, children, much of gold and silver, branded beautiful horses, cattle and well-tilled land. This is the pleasure of the present world's life; but Allah has the excellent return with Him.(2)

The prophet Muhammad (peace be upon him)said:"Three items of this world were made attracted to me: women, perfume the pleasure of my eyes is in prayer" (3)

Islam prevent his followers in respect to unnaturally behavior in all areas of life also forbids controlling of the sexual behavior because Islam is the natural religionand does not conflict with any further requirements in any time. Within the human need framework in sexual relationships proved that the efforts of Islam to raise them civilized.

The Islam instituted for Muslims to regulate the use ofthe sex. In fact, he sets the mode for the better advancement of man, if hefollows the Islamic rules on the subject.

Also looks at the proper use of the sex as an act of worship. A Muslim would reward when he practicesthis act, as he rewarded when he does any other acts of prescribed types ofworship.

The only acceptable wayfor sexual satisfaction in Islam is a lawful "marriage".

Islam urgesMuslims to seek marriage and encourages them to practice it. The prophet Muhammad (peace be upon him) says:"Whoever is financially capable of marriage but does notmarry, he does not belong to me" (4)

Islam regards marriage as a natural necessity in order toachieve tranquility and peace of mind for the Muslim. To the society, heregards marriage as a place to foster love, affection, closeness. Further, he regards it as a requirement to maintain thehuman race. Yet, he regards it as a mean for better moral values,preservation of the moral values of thehuman society.

Thus, neglecting marriage or rejecting it regarded as a denialof all the normal human behaviors and pure code of social ethics.Moreover, one of the objectives of marriage is to protectboth spouses against indulgence in unlawful sexual practices that may lead tocorruption and immoral acts in the society.Islamadvises him to refuses to degrade Believers to the stateof lower creatures, such as animals. Animals alone are left to practice sexualfreedom as they wish and without any restrictions. Islam regards it a great sinfor man to place his semen in a womb that is unlawful to him.

\section{Expurgation:}

Islam guides his followers to take purity. And also directs by which they would be, Allah willing, morally respectable and productive. 
AYoungman came to Muhammadasking him to permit him to practice adultery, as he cannot live without it, after embracing Islam. The Companions loudly rejectedhis appeal and denied it whole-heartedly. However, Muhammad(peace be upon him) called him closer to him and said, which reads as follows: "Do you accept your mother committing adultery?" The young man replied negatively. Thus, Muhammad said, which readsasfollows:" As such, other people refuse to see their mothers being indulgent in adultery. Muhammad further asked him, which reads as follows:" Do you accept your sister committing adultery?" The young man replied negatively. Thus, Muhammad said, which reads as follows:" As such, other people refuse to see their sisters committing adultery as well". Muhammad further asked, which reads as follows:" Do you accept your daughter committing adultery?" The young man replied negatively. Thus, Muhammadsaid, which reads as follows:" As such, other people refuse to see their daughters committing adultery as well". Thus, we notice that Muhammad was not harsh at all on the Youngman, but he rather prayed for the well-being of this young man saying:" Oh Allah! Purify the heart of this young man, chastise his private parts, and enable him to lower his gaze". This young man is reported to have said:" By Allah! I had never sought unlawful relations again ever"(5)

Islam does not condone a blind and uncontrolled satisfaction of personal whims and caprices.

\section{Marriage in Islam:}

Islam commands its followers to marry as early as they are able. Muslims should not fear poverty nor should they apprehend increase of family members as result of marriage, and thus, because of that, they stay away from marriage.

Allah says:"Marry those among you who are single, or the virtuous ones among your slaves, male or female: if they are in poverty, Allah will give them means out of His Grace: for Allah encompassed all and Chenoweth all things".(6)

Moreover, Muhammad(peace be upon him) said:"Allah takes it upon Himself to help three types of people. These are a warrior, who is striving in the cause of Allah a contracted slave, who wants to pay off the value set for his freedom of slavery, and, a person, who seeks marriage to chastise himself"(7)

If male Muslim cannot afford to marry because of poverty, he commanded to chastise himself. Allah states in Quran:"Let those who find not the wherewithal for marriage keep themselves chaste, until Allah gives them means out of His Grace".(8)

Muhammad(peace be upon him) gives advice that makes it easier to a certain extent for a person, who is unable to marry for dearth of marriage expenses. This advice harnesses his desire to marry and enables him to control his sexual desires. Muhammad (peace be upon him) said:"Oh young men! Whoever is capable to afford the expenses of marriage let him do so. Marriage helps one control his eyesight and chastise his private parts. But, he who can't afford the marriage expenses let him observe fast as it would as a protector for him" (9)

Islam permits Muslims to satisfy their sexual needs only through lawful marriage. Islam controls and organizes the sexual behavior and needs. Allah order to develop mutual understanding and take agreement must be secured for a marriage relationship between spouses. Both spouses to be must have witnesses to testify that marriage contract. And the woman in Islam is protected by such contract against unlawful relationships. Islam established the basis of a nucleus family that is nourished by the mother, and supported by the father. This is the system that Islam accepts and maintains for its Believers and as such, it ruins all other unlawful and meaningless relationships"

\section{Sexual Relationship in Islam:}

Islam bans all actions lead to arouse the sex other than the permissible and also bans all activitieslead to unlawful practices. Sexuality may be attained with mutual consent of both the parties involved or may tend to discharge it by unlawful meansi.e. homosexual, lesbian, or masturbationare unlawful in Islam.

ALLAH says: and tell the believing women to lower their gaze, and protect their private parts and not to show off their adornment except Only that which is apparent, and to draw their veils All over Juyubihinna and not to reveal their adornment except to their husbands, their fathers, their husband's fathers, their sons, their husband's sons, their brothers or their brother's sons, or their sister's sons, or their women, or the slaves whom their Right hands possess, or old male servants who lack vigor, or small Children who have no sense of the shame of sex. And let them not stamp their feet to reveal what they hide of their adornment. And all of you beg Allah to forgive you all, O believers, that you may be successful.

And marry those among you who are single and the Sâlihûn of your slaves and maidservants. If they were poor, Allah will enrich them out of his Bounty. And Allah is All-Sufficient for his creatures' needs, All-Knowing. (10)

\section{Islam commands to apply the followingsin order to restrict sexual intercourse:}

- Islam order to avoid any Relation between male and female children while sleeping together alone in the same bed or room.Muhammad(peace be upon him) said:“......Separate when they sleep at that age". (11) 
Muslim women should segregate from stranger males,however, gave permission to the "agedwomen", to wear normal modest attire. Allahsays:"Such elderly women as are past the prospect of marriage, there is no blame on them if they lay aside their outer garments, provided they make not a wanton display of their beauty: but it is best for them to be modest....".(12)

$\square \quad$ Islam order to protect and lower the eyesight against all unlawful scenes. It may generate a sexual desire.Allah says: Tell the believing men to lower their gaze, and protect their private parts. That is purer for them. Verily, Allah is All-Aware of what they do. And tell the believing women to lower their gaze, and protect their private parts and not to show off their adornment except only that which is apparent....(13)

Furthermore, Muhammad(peace be upon him) said:"The look is a poisonous arrow of Iblis"(al-qazai, Muhammad bin salamah bin jafar, Musnad Al-shihaab al-qizaai, Moassetu al-risalah, Berut, 1986, H: 282)

- Muslims areordered not to prolong such unlawful looks as in hadith: "don'tcontinue with looking, as the first look is permitted for you, while the second is not"(14)

- Islam order adult and mature males and females to seek permission when entering any private residence. Allah says: "Oh believe Let those whom your right hands possess, and the among you who have not come of age ask your permission, on three occasions, before morning prayer; the while you take off your clothes for the noonday heat; and after the late-night prayer: these are your three times of undress: outside these times it is not wrong for you or for them to move about attending to each other.."(15)

Islam bans listening to sexually oriented songsbecause these are prepare mentally to commit unlawful banned sexual practices.

$\square \quad$ Islam bans Muslim malestoo alone with any female, without any lawful relationship. Muhammad(peace be upon him) explained the best method to be with a female saying: "A man must not be alone with a woman, unless one of her male immediate relatives is present withthem"(16)

ㄴ Islam bans on wife to describe the physical details of another woman. It may slightest attraction of that married man to the other woman.Muhammad(peace be upon him) said: "A woman must not see another woman, and then describes the details of that woman to her husband".(17)

Islam bans women to go out of their homes with full make up andPerfume. May be this practice would attract the male's attention. And also bans a female to speak softly tone with a malewho is not related to herto protect against males.

口 Islam bans nudity and displaying women's physical attractions.Allah says:And they prevent others from Him and they themselves keep away from him, and they destroy not but their own selves, yet they perceive not.(18)

Islam bans a woman to travel alone. She must travel with animmediate relative described earlier as Mahram, one of the following relatives: a husband, a father, a brother, or a relative whom she does not allowed marrying on a permanent basis. Muhammad (peace be upon him) said:"A woman must not travel without a Mahram...."(19)

․ Islam instructs women allowed to appear before lawful relatives to do so with Casual clothes and ornamentations. Allah says:

"...and not display their beauty except to their husbands, their fathers, their husbands' fathers, their sons, their husbands' sons, their brothers or their brothers' sons, or their sisters' sons, or their women, or the slaves whom their right hands possess, or male servants free of physical needs, or small children who have no sense of the shame of sextant that they should not strike their feet in order to draw attention to their hidden ornaments. Moreover, Oh Believers! Turn you all together towards Allah that may attain Bliss" (20)

$\square \quad$ the acts are permitted for engaged persons are below: the meeting, touching, seeing, and acting like a couple of the prospective spouses with each other before marriage without marriage agreement is banned, after engagement. Until they do not perform the marriage agreement.

\section{Ideal Relationship:}

A fun with the wife is not confined to the bed only. A husband may have fun with his wife all the time, if privacy for both is well secured and maintained.

\section{At home:}

Aisha was once asked, which read as follows: "What would Muhammad do first when he entered his home? She replied: He brushed his teeth with his Siwak, the wooden toothbrush. I would think that he cleans his mouth and makes it smell better in order to hug his family and kiss them". (21)

\section{Outside the home:}

Fun with the wife is permitted at all times and at all places if the full privacy is secured and maintained. Nobody must see a husband and wife having fun or playing with each other in public. It is an unacceptable practice to talk about what takes place between a husband and his wife in privacy. 


\section{Marriage procedure in Islam: \\ Criteria of selecting partner:}

Islam advice to marriage seekers to select relationship will be establishing a beloved and caring family. Allah says:"Marry those among you who are single, or the virtuous ones amongyour slaves, male or female: if they are in poverty"(22)

Muhammad(peace be upon him) explainedthese issues and emphasized the everlasting factor for marriage, which is righteousness. Muhammad(peace be upon him) said: "A woman would be sought for marriage for four: her wealth, beauty, lineage, and for her Islam. May Allah bless your hands; seek the one with a strong commitment to faith" (23)

\section{To look another:}

Both must satisfy to the basic essential requirements of marriage.Therefore, Islam permits both spouses to look at each other. A man came to Muhammad (peace be upon him) and informed him that he sought marriage from specific woman of Ansars. Muhammad (peace be upon him) said:"Did you look at her? The man answered negatively. Muhammad said: Look at her. There is something about the eyes of Ansari women"(24)

Muhammad (peace be upon him) explained the wisdom of the lawful sight of the bridegroom to the bride. This is a wise advice so as the bridegroom would not regret later if had seen the bride before marriage.

\section{The marriage agreement:}

\section{Islam requires specific conditions for marriage.}

First condition: the acceptance and approval of both families. Muhammad(peace be upon him) said: "A widow or divorcee must not be married unless she approves it. The virgin, also, must not be marrying unless she is sought permission. The Companions asked: How could we seek her permission? He replied: If she observed silence it means she gave her permission".(25).

So if a woman is forced to marry without her willing, she has the right to break thatMarriage. This is based on Hadith when a woman called Khansabint Jutham was forced to marry, without her willing. She came to Muhammad (peace be upon him) and informed him that her father offered her in marriage without her willing.

Muhammad(peace be upon him) declared that marriage cancelled and void. The role of a legal guardian is also another requirement of avalid marriage. This based on the Hadith reported of Muhammad (peace be upon him) saying: "Amarriage would not be valid unless a guardian and two just witnesses are present" (26).

Second condition: if there is no guardian, the guardianship would automatically transfer to the judge or local authoritiesas per the Hadith:"The governor is the guardian for who has no guardian"(27)

Third condition: adowry: Adowry must be paid to the bride. Even if it is not mentioned at the time of marriage one will still be obliged to pay it. And there is no maximum limit.

Allah says:“And give the women their dower as a free gift”.(28)

Islam orders a wedding party to celebrate this agreement. Islam exhorts the invitees for a wedding party to attend it, unless he has valid excuse. And urges the people who attend the wedding meal party to pray for the inviters.

Muhammad (peace be upon him) says: "May Allah blesses her for you, may Allah bless you, and may Allah gather both of you on good thing.(29)

\section{The Weddingnight mannerisms:}

After the arrival of the bride at her husband's home both will meet for the first time. This is the first meeting of a new pair so this time advised to presenthim in a good manner, with sweet conversationsDoing so would bring the two spouses closer together.Firstly It is an act proved by Sunnah to hold the hair bangs of the bride andpray as in Hadith:"Oh Allah! I seek of you the best of this woman and the best of her characteristics. Oh Allah! I seek refuge with you to protect me against all the evils of this woman and her evil characteristics"(30)

Islam, in fact, places a great value for the fun between the two spouses. Moreover, he encourages Decent grooming promotes love and increases affection between spouses.Allah says: Moreover, women shall have rights similar to therights against them, according to what is equitable; but men have a degree over them. And Allah is exalted in Power, Wise"(31)

Both are permitted to see each other in the nude. Both are also entitled to enjoy one another to the utmost. Mu'awiyah asked Muhammad(peace be upon him):"Oh Messenger of Allah! To what extent should we protect our private parts? Muhammadhas replied: Protect your private parts except from your spouse or those whom your right hand possesses" (32) 
Both spouses are entitled to enjoy each other fully in terms of sexual intercourse in any position, if the husband approaches his wife in the proper place.Muhammad(peace be upon him) says: "You may approach her from the front, or from the back, provided that you avoid the Anis and while the wife is in menses" (33)

This Hadith means that a husband must avoid doing anything with his wife while she is in menstruation period. Similarly, a husband and wife may enjoy each other, while in menstruation, if they avoid the actual intercourse.

The husband must play with his wife, talk to her nicely, and kiss her in order to arouse her sexually. And husband must wait for his wife to satisfy her sexual desire. Muhammad (peace be upon him) says: "If a husband has an intercourse with his wife he must be truthful with her. If he got sexually satisfied before she does, then he should wait for her to get her satisfaction" (34)

It is also Sunnah to perform a completeAblutionby taking a full bath, or a partial ablution, as one does to offer a prayer, if the husband desires to have another intercourse with her. Muhammad(peace be upon him) said: "If a husband has an intercourse with his wife once, and wanted to repeat it again, let him perform an ablution" (35)

As long as the wife is not in her monthly periods the spouses may engage in sexual intercourse as long as it in the proper permitted place (vagina), whatever position is comfortable to both. Anal and oral sex is not permitted. So the different position of intercourse allowed for the both of husband and wife. Islam permitted for any position for this act.

And regarding to these position as in Quran and Hadith these are sitting and lying down whilst engaging in sexual contact.

\section{Sex during Monthly Periods:}

ALLAH says in Quran: they ask you concerning menstruation. Say: that is a harmful thing for a husband to have a sexual intercourse with his wife while she is having her menses, therefore keep away from women during menses and Go not unto them till they have purified. And when they have purified themselves, Then Go In unto them as Allah has ordained for you. Truly, Allah loves those who turn unto Him In repentance and loves those who purify themselves. (36)

So we can say during the days of menstruation it is banned for a husband to cohabit with his wife and permitted for his other parts of her body.

Today latest medical research shows this Qur'anic truth for both the spouses to cohabit during the wife's specific days (monthly, after childbirth etc...)

\section{Physical Preparation:}

It is cleared about physically preparation means one should brush one's teeth, use perfume and ensure of nobody or disheveled appearance. This should be done at all times but this time it takes on a greater significance. Clean cloth should be used on bed besides that two small towels should be utilized to clean the private parts after intercourse.

\section{Psychological preparation:}

Psychological preparation must be made for intercourse. Because this increase enjoyment and is much more mutually considerate. So each should express their desire for the other both verbally and practically.

\section{Time To Have Sex:}

There are few times every month but after the monthly periods the most women develop an intense craving for sex. The husband may be recognize these timings and endeavor to fulfill her desire her desire. This will increase her love and respect for him. Also wife may be remembering the husband also her needs and she also be willing to cater for them. Finally this will increase love and respect between them. But generally the best timefor this at least three hours after having eating.

\section{While Taking A Bath:}

A fun with the wife is not confined to the bed only. A husband may have fun with his wife all the time, if privacy for both is well secured and maintained. Aisha said: "Muhammadand I bathed of the same pot of water that we placed between both of us. He would beat me to take the water until I say to him, let me have some! Let me have some!"(37)

\section{with Wife outside the House:}

With wife at all times and at all places husband can behave if the full privacy is secured. And No one see them having fun or playing with each other. Aisha said: "While I was young, before I put much weight on me, Muhammad and I was on a trip. He advised his Companions to go-ahead of him and called me to race with him. I beat him in running. Then, Muhammaddid not ask me anymore to race with him for a while. Later on, after I gained weight and forgot thatl have beaten him in the race, I was again on a trip with him. He advised his Companions to go ahead of him for a distance. Then, he told me come let us have a running race! I 
totally forgot the previous incident when I beat him in the race. Aisha commented: Oh Messenger of Allah! How can I race with you and I am as heavy as you can see? Hesaid: You must do it. Thus, we raced and he beat me this time. He began laughing and said: Oh Aisha, this win by that win in the race" (38)

\section{Wife's right on her husband:}

It suffices here to list some verses of Quran and Ahadith that illustrate the rights of the wife in Islam.

1- $\quad$ Allah says:"On the contrary live with them on a footing of kindness and equity. If ye take a dislike to them, it may be that ye dislike a thing, and Allah brings about through it a great deal of good". (39)

2- $\quad$ Allah says:"And women shall have rights similar to the rights against them, according to what is equitable; but men have a degree over them. And Allah is exalted in Power, Wise". (40)

3- $\quad$ Muhammad said:"The best among you is one who is best to his family [wife], and I as Allah's Messenger am the best among you to my family". (41)

4- One of the sahabah asked Muhammad: "What is the right of the wife? Muhammad (peace be upon him) said: To feed her if you eat, clothe her if you clothe yourself, don't slap her on the face, don't be nasty to her and don't be away from her except while both of you are at the same house" (42)

Husband's rights over his wife:

\section{The following some famous rights from Quran and Ahadith concerning the husband's rights on his wife.}

1- $\quad$ Allah says describing the righteous women,"Therefore the righteous women are devoutly obedient, and guard in absence what Allah would have them guard". (43)

2- Muhammad said:"The best of women is the one who pleases you if you look at her, obeys you if you command her [to do a lawful item], and protects your privacy and wealth if you are absent". (44)

4- $\quad$ Muhammad said:"If a woman maintains her five daily prayers, observes the fast of the month of Ramadan, protects her private parts [by not committing adultery or fornication], and obeys her husband, she would be given the choice to enter paradise, Paradise through any gate she likes" (45)

5- Muhammad said:"If I were to command someone to prostrate to another person, I would have commanded a wife to prostrate before her husband". (46)

\section{Sexual Freedom and Confusion:}

Islam bans all types of fornication labeling in Islam major sins. Also bans all acts related to unlawful may lead to commit adultery. Here are some of the results:

\section{Epidemic and fatal diseases:}

Such diseases may spread very wide in the community.

Allah says:"Nor come nigh to adultery: for it is a shameful and an evil, opening the road".(47)

Adultery would abolish brightness from the faces of the practicing person. Adultery would also cause a person to face poverty. Thus, adultery would shorten the life span of a person because of the potential diseases that may endanger his life and possibly cut it short.

\section{Illegitimate children:}

Such children are deprived the Normal care and custody of real loving parents. As a result, such children would lack the objective and proper guidance and direction in their lives. No one, other than the real parents, could offer an honest, truthful, and meaningful guidance to a child. Consequently, such deprived class of children would grow up to be uncontrolled and full of hatred to the rest of the society members. Anna Freud, in her book Children without Families, comments on the psychological disorders that cannot be corrected by a psychiatric specialist except with great difficulties

\section{Psychological disorders:}

Unlawful sexual relationships would lead to a lot of psychological diseases and disorders. People who practice and maintain such unlawful relationships would develop unease, lack of personal happiness and satisfaction, inferiority complex, guilt, and self-discern because of practicing unlawful sexual relationships. Allah says:

"And among His Signs is this, that He created for you mates from among yourselves, that ye may dwell in tranquility with them, and He has put love and mercy between your: verily in that are Signs for those who reflect". (48)

\section{Sexual Confusion:}

Sexual confusion leads to moral confusion in the society. It is a well-established fact that money could easily trap and lure people to do anything evil. Money also enables a person to get all what he likes in terms of pleasures and satisfaction. Thus, if those who are practicing unlawful satisfactions lack the needed funds, 
they may commit any type of crime to satisfy their needs. Such individuals may steal, cheat, molest, rape, lie, deceive, bribe, or even kill in order to get what they want. They do not care where or how they get the needed funds, even if this is on the account of others.

\section{Descending of the Wrath promised by Allah}

Allah promised the communities where adultery and fornication practiced or condoned, to receive one of the severest punishments.

Additional Marriage Preference:Islam urges Muslims to intercede between two loving spouses.A Muslim guardian of a woman may, based on the acceptance and approval of the woman, propose her for marriage to someone who is well acquainted with his character and qualities. A guardian is usually keen to serve the interest of the woman he entrusted him for guardianship. Allah says: "And when he arrived at the watering in Madyan, he found there a group of men watering, and besides them he found two women who were keeping back. He said: What is the matter with you? They said: We cannot water untilthe shepherds take back: and our father is a very old man. Therefore, he watered for them; then he turned back to the shade, and said my Lord! Truly am I in need of any good that Thou dost send me! Afterwards one of the came to him, walking bashfully. She said: My father invites thee that he may reward thee for having watered for us. So when he came to him and narrated the story, he said: Fear thou not: hast thou escaped from unjust people. He said: I intended to wed one of these my daughters to thee, on condition that thou serve me for eight years; but if thou complete ten years, it will be from thee. However, I intend not to place thee under a difficulty: thou wilt find me, indeed, if Allah wills, one of the righteous. He said: Be that between thee and me: whichever of the two terms I fulfill, let there be no ill will to me. Be Allah a witness to what we say". (49)

\section{Some Banned Sexual Relationship In Islam: HOMOSEXUALITY:}

It destroys the very fabrics of family and society in general. Its religious ruling can be understood from the following statement of Quran regard to destruction of a homosexual nation: "Verily, You practiceyour lusts on men instead of women. Nay, but You are a people transgressing beyond bounds." and the answer of his people was only that they said: "Drive them out of yourtown;these are indeed men who want to be pure!" Then we saved Him and his family, except his wife; she was of those who remained behind. And we rained down on them a rain. Then see what was the end of the criminals, polytheists, sinners, etc. (50)

Thereafter it can also be understood that is not only the view of Islam but also the view of all school of thoughts, apart from those who engage in it.

\section{MASTURBATION:}

Masturbation is also banned for both male and female so there are many Ahadith that state it's prohibition in very clear warnings because these are numerous harms in masturbating, including that of potential impotence. And in regard to celibacy before marriage it is the only way. But it is not an alternative to marriage. So we can say and understand that only sex within marriage is permitted within Islam.

\section{Harms Of Adultery:}

Islam also banned all casual sexual relationship ALLAH says: and come not near to the unlawful sexual intercourse. Verily, it is a shameful deed, and an evil Way. (51)

And Muhammad (P.B.U.H) commented: O Muslim beware of adultery for indeed it is an accompanied by six evil consequences: three in this world and three in the hereafter. The three in this world are: loss of radiance from the face, reduction in life span and continuous poverty.

\section{Conclusion}

We have presented in this article some of the major Islamic sound point on sex. We aim to offer some introductory remarks about this very important issue of human life, and the method of Islam follows to govern it to become as one of the acts of Islamic worships.

A Muslim would be rewarded if he/she uses sex in the manner described and approved by Allah and His Messenger. And hoped to urge a non-Muslim to further his knowledge about Islam; which offers the best way of life.

Islam encompasses all aspects of life, the private, and the public as well. In fact, if a Muslim were serious about his Islamic practices, his reward would continue reaching him, even after death. If a Muslim left a good legacy or guidance behind him, or if he even guided and directed people to a certain good practice, he would continue to receive the promised reward after his departure of this world.It is, therefore, safe to say that Islam is the greatest religion that accompanies and guides man in every step of his life and affairs.

\section{References:}

[1] Al-Quran: 24:30-31

[2] Al-Quran: 3/14

[3] Al-Nasai, Ahmed Bin Shoaib, 1420h, Sunan Al-Nasai, Dar UI Marifah, Berut, Ishrat UI Nisaa, Chapter Of Hubebaa Al-Nisaa, H:3949

[4] Maajah, Abu Abdullah Muhammad bin yazeed, 1991, Sunan ibn-e-Maajah, dar-ul- Fkir, Berut, 1991, book of Al-nikah, chapter of fazal-e-nikah, h: 1842 
[5] Ahmed bin Hanbal, 1990, Musnad Ahmed, Moasse-tu-risalah, Berut, musnad ul Sahaabah, hadith Abu umamah al-baheli, $\mathrm{H}: 21654$

[6] Al-Quran: 24/32

[7] Muhammad bin Hibbaan, 1993, Sahih ibn-Hibbaan, Moassetu al-risalah, Berut, the book of Hajj, the chapter of Hadyo, Hadith 4092

[8] Al-Quran: 24/33

[9] Al-bukhari, Muhammad bin Ismail,1987, Sahih ul Bukhari, dar ibn-e- kaseer, Berut, book of Nikah, chapter of qaul ul-rasool man istataa, $\mathrm{H}: 4780$

[10] Al-Quran: 24/31

[11] Abu daod slaiman bin ashas, 1998, Sunan abi daod, dar-ul-fikr, Berut, book of salaat, chapter of mata uoomar al-ghulam bissalaat, $\mathrm{H}: 423$

[12] Al-Quran: 24/60

[13] Al-Quran: 24/30

[14] Al-hakim, Muhammad bin Abdullah, 1990, Al-mustadrak ala al-sahihain, dar-ul-kutab al-ilmiyyah, Berut, book of Nikah, $\mathrm{H}: 2720$

[15] Al-Quran: 24/58

[16] Al-Bukhari, book of Nikah, Hadith: 4939-2865

[17] Musnad Ahmed

[18] Al-Quran: 6/26

[19] Al-bukhari, book of Hajj, the chapter of al-mohsar wa jaza al-said, $\mathrm{H}: 1772$

[20] Al-Quran: 24/31

[21] Hibban, Sahih ibn-e-hibban, book of al-tahaarah, chapter of sunan ul wudhoo, $\mathrm{H}: 1080$

[22] Al-Quran: 24/37

[23] Muslim, book of al-rizaa, chapter of istehbaab -ul-Nikah, H: 2739

[24] Muslim, book of Nikah, chapter of nadb ul nazar ilaa waje al-maraa, $\mathrm{H}: 2630$

[25] Ibn-e-Maajah, Book of Nikah, chapter of istemaar ul bikr wa sayyab, H: 1866

[26] Ibn-e-Hibbaan, book of Hajj, chapter of al-Hadyoo, $\mathrm{H}: 4138$

[27] ibn-e-Hibbaan, book of Hajj, chapter of al-Hadyoo, $\mathrm{H}: 4138$

[28] Al-Quran: 4/3

[29] Al-hakim, Al-mustadrak ala al-sahihain, the book of Nikah, H: 2676

[30] Abu daod, book of Nikah, chapter of jame ul nikah, $\mathrm{H}: 1858$

[31] Al-Quran: 2/228

[32] abu daod, book of Hammaam, chapter of ma JA fi al-tarri, H: 3519

[33] al-tirmidhiabu yalaa, musnad, 1990, berut, dar ul fikr

[34] al-tirmidhi, Sunan al-tirmidhi, Abwaab ul taharaah, Bab ma jaa izaa aradaa a yaoodaa

[35] Al-Quran: 2/222

[36] Al-Bukhari, book of al-ghusl, chapter of man's bath with wife, Hadith: 246

[37] Abu daod slaiman, dar-ul-fikr, Berut, 1998, book of al-jihad, chapter of fi-alsabq al-arajul, Hadith 2227

[38] Al-Quran: 4/19

[39] Al-Quran: 2/228

[40] Ibn-e-maajah, sunan ibn-e-maajah, book of al-nikah, the chapter of husn moashrah tul nisah, Hadith : 1973

[41] abu daod, slaiman bin ashas, dar-ul-fikr, Berut, 1998, book of al-Nikah, chapter of Haq ul maraa ala zaujehaa, Hadith 1843

[42] Al-Quran: 4/34

[43] abu daod tayalsi, Musnad tayalsi, dar-ul-hadith, berut, ahadith ul nisaa, ma asnadaa abu hurairah, Hadith: 2432 


\section{ISSN:2321-1098}

[44] Muhammad bin Hibbaan, Sahih ibn-Hibbaan, Moassetu al-risalah, Berut, 1993, the book of Hajj, the chapter of Hadyo

[45] Muhammad bin Hibbaan, Sahih ibn-Hibbaan, Moassetu al-risalah, Berut, 1993, the book of Hajj, the chapter of Hadyo, Haidth : 4223

[46] Al-Quran: 17/29

[47] Al-Quran:

[48] Al-Quran: 28/22

[49] Al-Quran, 7/81-84

[50] Al-Quran: 17/32

[52] Baihaqi, al-kabair 